\title{
Car Ride
}

National Cancer Institute

\section{Source}

National Cancer Institute. Car Ride. NCI Thesaurus. Code C113418.

A journey in an automobile. 